May 2014

\title{
Then \& Now: The Changing Face of the Library Professional
}

Adrienne Mathewson

desertrhythm@gmail.com

Follow this and additional works at: https://scholarworks.sjsu.edu/ischoolsrj

Part of the Scholarly Publishing Commons

\section{Recommended Citation}

Mathewson, A. (2014). Then \& Now: The Changing Face of the Library Professional. School of Information Student Research Journal, 4(1). https://doi.org/10.31979/2575-2499.040101 Retrieved from https://scholarworks.sjsu.edu/ischoolsrj/vol4/iss1/1

This article is brought to you by the open access Journals at SJSU ScholarWorks. It has been accepted for inclusion in School of Information Student Research Journal by an authorized administrator of SJSU ScholarWorks. For more information, please contact scholarworks@sjsu.edu. 


\section{Then \& Now: The Changing Face of the Library Professional}

\section{Keywords}

Student Research Journal, San Jose State University, Library Information and Science

\section{About Author}

Adrienne Mathewson is the Editor-in-Chief of the Student Research Journal. She resides in Albuquerque, New Mexico and provides freelance writing and editing services. 
Welcome to the first issue of Volume 4 of the Student Research Journal $(S R J)$. As we publish the fourth volume of this student-run, student-governed scholarly journal, we continue to provide researchers and authors with critically evaluated articles of concern to library and information science professionals and students. I'm proud to say that we are reaching the twenty-thousand download mark of our articles from readers around the world.

Our editorial team members continue to provide critical review of the submissions received by $S R J$ under guidance of the Managing Editor, Sara Kelso. Team members for this issue were Jason Baker, Tacoma Tomlinson, Brighid Mooney-Gonzales, Laura Stanger, Lawrence Mak, and Alex Post as content editors and Stephanie Routhier-Perry as copy editor. All of the team members agree that one of the most helpful aspects of working on the journal is that the training and experience in evaluating manuscripts helps sharpen their own writing skills. Editors learn that preparing a manuscript for publication in a scholarly journal requires a higher level of preparation and skill than that required to prepare a paper for a graduate level class.

Team members are encouraged to submit their own paper to be evaluated through the strict double-blind peer review, with the exception of the Managing Editor and Editor-in-Chief. In order to maintain the integrity of the process, neither the peer reviewers nor the copy editors are allowed access to author identity until a manuscript is accepted for publication. This process allows the current content editors the opportunity to utilize skills learned through their work while at the same time, protects the double-blind peer review process.

In this issue, it is apparent that working on the journal is beneficial to the editors; I'm proud to announce that two of our own team members have articles that passed the extensive double-blind peer review. In fact, our graduating editorial team member, Brighid Mooney-Gonzales, is the recipient of the 2014 LITA/Ex Libris Student Writing Award for her paper titled "Linking Libraries to the Web: Linked Data and the Future of the Bibliographic Record", as well.

This issue's theme celebrates the changing face of the library professional and the willingness of librarians to incorporate rapidly changing technology into their world in order to continue to provide free and accessible information to the public.

The Invited Contribution is submitted by Dr. Debra L. Hansen, a professor at SLIS; her essay, "First Class: Pioneering Students at San José State University's School of Library and Information Science, 1928-1940", relates the story of the lives of the first students of the SLIS program, and the development of the program itself. According to her article, there were twelve full-time and five special studies students enrolled in the first year. Part of the requirements for admittance for the full-time students were that they had to "possess reading knowledge of two languages" and two years of college. The special students were 
allowed to use their previous library training or work experience in lieu of the requirements. Dr. Hansen is the author of the book, A Pioneering and Independent Spirit: The History of San José State University's School and Library and Information Science, published in 2010.

The Library and Information Science program has developed considerably since this first class of students and Brighid Mooney-Gonzales' article reflects that progress in its discussion of how best to prepare LIS students for metadata librarianship. "Preparing LIS Students for a Career in Metadata Librarianship," offers original research on the various educational and work paths a library student can pursue for the goal of being a metadata librarian. The article explains the difference between cataloguing and metadata and discusses how these two fields overlap and complement each other. I found it interesting that while Dr. Hansen discusses the requirement for the first library students to know two languages, now it's becoming a requirement for modern librarians to know the language of coding and technology.

Stephanie Routhier-Perry's literature review on digitization and digital preservation provides an overview of current literature on the state of digital preservation. She defines digitization as the conversion of traditional, analog materials into an electronic, digital copy. This differs from digital preservation, which is defined as conservation of digital material including items born digital and those that have been digitized. Copyright and cost issues play into the digitization and digital preservation issues, as Routhier-Perry cites research indicating it may be time-consuming, expensive, and difficult to establish copyright on older or digitized materials.

Privacy is another issue that arises in digitization; Camila Z. Tessler addresses that concern in her article "Privacy, Restriction, and Access: Legal and Ethical Dilemmas". Tessler, a recent LIS student at the University of Arizona, contends that "privacy is the crux of any archive's collection policy" due to the restrictions placed on a collection. She concludes that solutions to this problem can be found in developing stronger copyright and restricted materials policies, strong accession policies, and strong community input.

As this first issue of SRJ's fourth volume is published, I'd like to acknowledge and thank Dr. Anthony Bernier, our faculty advisor; Suzanne Scott, $S R J$ 's first Editor-in-Chief; and all the dedicated editorial team members from this issue and past issues. The Student Research Journal has proven its worth as it advances scholarly research in the library information and science field, to both researchers and LIS graduate students worldwide. 